\title{
Effect of domestic wastes on the benthic marine communities of southern California
}

\author{
D. J. Reish \\ Department of Biology, California State University; Long Beach, California, USA
}

\begin{abstract}
A total of 3,785 million $l$ of domestic wastes is emptied into the marine waters of southern California each day. Over $85 \%$ of these wastes receive primary treatment before discharge into offshore waters. Most of these wastes are discharged at four localities: El Segundo (Los Angeles City), White's Point (Los Angeles County), Newport Beach (Orange County), and Pt. Loma (San Diego City). While some studies were conducted at these localities prior to 1970, all of these sanitation districts have been monitoring the benthic environment since 1971-1973. Some predictions on the effect of domestic discharges on benthic life were made based on the amount of primary effluent discharged per day. If the amount discharged into open oceanic waters is less than 18 million l/day, then a biological enhancement is noted with an increase in biomass, number of species and specimens, and diversity. If the amount of discharge exceeds $40-180$ millions $1 /$ day, then the biomass, number of specimens, and area affected is increased, but the number of species, diversity, and richness is decreased. A faunal index was devised by the personnel at Southern California Coastal Water Research Project to represent these generalities graphically.
\end{abstract}

\section{INTRODUCTION}

Domestic wastes from southern California cities and communities are discharged for the most part into offshore marine waters in depths of 6 to $100 \mathrm{~m}$. Treatment is largely primary with some secondary; raw sewage is discharged only at Santa Catalina and San Clemente Islands. Of the $3.8 \times 10^{9} 1$ day of domestic wastes which are emptied into southern California marine waters, over $80 \%$ originates from the metropolitan Los Angeles-Orange County area (Schafer, 1978; Table 1). The discharge at Hyperion is unique in that the sludge is discharged at the head of a submarine canyon located 11.6 $\mathrm{km}$ offshore in $100 \mathrm{~m}$ depth.

Since the discharge at Hyperion Sewage Treatment Plant has been monitored for benthic animals for over 20 years and the other major discharges have been studied since the early $1970 \mathrm{~s}$, an analysis of these data affords us the opportunity to measure what the long-term effects of these wastes have been on the marine benthos. With these data bases, it has been possible to record man-caused and natural environmental changes in the vicinity of these discharges which, in turn, assist us in evaluating the effect of domestic wastes on the marine ecosystem. Such an analysis is especially appropriate since Public Law 92-500 of the U. S. Congress requires a change from primary to secondary treatment by July 1,1983 . In addition, other countries are considering the construction of large pipelines to divert their wastes into open oceanic waters from estuaries. 
It is the purpose of this brief report to describe the benthic conditions around the sewage outfalls of southern California which may be of assistance to others who are contemplating this method of domestic waste disposal.

\section{EFFECT OF DOMESTIC WASTES ON THE BENTHOS: CASE STUDIES}

\section{San Elijo}

The cities of Cardiff and Solano Beach discharge 7.5 million 1/day of primary effluent $3.7 \mathrm{~km}$ from shore at a depth of $15 \mathrm{~m}$ at San Elijo. The benthic fauna was surveyed before and after the construction of the pipeline and after two years of

Table 1. Domestic wastes discharged into southern California marine waters (1977)

\begin{tabular}{|c|c|c|c|c|}
\hline Location & $\begin{array}{c}\text { Flow } \\
\text { (million } 1 / d \text { ) }\end{array}$ & $\begin{array}{c}\text { Nature of } \\
\text { effluent }\end{array}$ & $\begin{array}{c}\% \% \text { of } \\
\text { total flow }\end{array}$ & $\begin{array}{c}\text { Area } \\
\text { affected }\end{array}$ \\
\hline Oxnard & 42.4 & Primary & 1.1 & $1 \mathrm{~km}^{2}$ \\
\hline \multirow[t]{3}{*}{ Hyperion (LA) } & 830.0 & Primary & 21.8 & 26 \\
\hline & 380.0 & Secondary & 9.9 & \\
\hline & 5.3 & Sludge & 0.1 & \\
\hline \multirow[t]{2}{*}{ Los Angeles County } & 1270.0 & Primary & 33.3 & 45 \\
\hline & 7.2 & Sludge & 0.2 & \\
\hline \multirow[t]{2}{*}{ Orange Co. } & 606.0 & Primary & 16.0 & 10 \\
\hline & 75.7 & Secondary & 1.9 & \\
\hline San Diego & 440.0 & Primary & 11.5 & 6 \\
\hline \multirow[t]{2}{*}{ Others (20) } & 75.7 & Primary & 1.9 & - \\
\hline & 75.7 & Secondary & 1.9 & \\
\hline$\Sigma$ & 3808.0 & & 100.0 & \\
\hline Total: Primary & 3307.0 & & & \\
\hline Secondary & 531.0 & & & \\
\hline Sludge & 12.5 & & & \\
\hline
\end{tabular}

operation the only measurable effect noted was a slight increase in the biomass in the vicinity of the terminus of the pipeline (Turner et al., 1965). Whether this increase was the result of the increase in organic matter or the result of natural variability is unknown.

\section{San Diego}

The City of San Diego discharges 300 million 1/day of primary effluent $3.2 \mathrm{~km}$ from shore at a depth of $64 \mathrm{~m}$ at Point Loma. The benthic fauna was studied for a year prior to commencement of operations in 1963. The domestic pollution indicator polychaete Capitella capitata first appeared at the terminus in 1965 (Turner et al., 1968). The biomass had increased significantly in the area surrounding the outfall by 1968 . The stressed community, which included C. capitata, occupied $6 \mathrm{~km}^{2}$ by 1977 (Bascom et al., 1978). 


\section{Los Angeles County-White's Point}

The County of Los Angeles discharges 1270 million 1/day of primary effluent and sludge through three diffusor pipes 2 to $3.6 \mathrm{~km}$ from shore at depths of $50-65 \mathrm{~m}$ at White's Point located on the Palos Verdes Peninsula. Monitoring of the benthos began in 1971 some three decades after the operations began. It was possible with the 1971 data to divide the benthos into three communities: (1) A stressed community dominated by Capitella capitata which was present in the vicinity of the discharge, (2) a community which extended beyond the stressed one which showed signs of being stressed by its reduced fauna, and (3) a natural diverse community located some distance from the discharges. In 1973-1975 the stressed community was reduced in area and by 1975-1977 the stressed community had essentially disappeared and the sediments no longer possessed a sulfide odor. However, in 1978-1979 the stressed community, dominated by C. capitata, reappeared and the sediments once again possessed a sulfide odor. Since there had not been any significant alteration in the nature and quantity of the discharge, other explanations were sought to explain this apparent temporary improvement of conditions followed by a degradation. The echiuroid worm Listriolobus pelodes, which measures several $\mathrm{cm}$ in length, first appeared off the Palos Verdes Peninsula coast in mid-1973 and by 1975 had settled in the vicinity of the terminus. These organisms live in the sediment and maintain permanent burrows which extend downward $30-50 \mathrm{~cm}$. Apparently, the movement of these animals within their burrows allowed the penetration of dissolved oxygen which oxidized the accumulated organic material. Reduction of the organic material led to an improvement in the benthic conditions. With the disappearance of $L$. pelodes, which was probably the result of natural causes, the organic material accumulated again leading to the re-establishment of stressed conditions. The area which is either stressed or degraded now totals $45 \mathrm{~km}^{2}$ (Bascom et al., 1978).

\section{Orange County}

Domestic wastes from Orange County are discharged into oceanic waters just north of Newport Bay. Up to 1971 primary effluent was discharged $2 \mathrm{~km}$ from shore in $20 \mathrm{~m}$ depth. This pipeline was abandoned and replaced with one extending $8 \mathrm{~km}$ from shore and emptying in $60 \mathrm{~m}$ depth. The discharge from this outfall totaled 681.7 million $\mathrm{l} /$ day in 1977 of which about $12 \%$ was secondary effluent. The changeover enabled one to measure the recovery rate of the previously affected area and to determine the rate of degradation around the new discharge.

Recovery at the old site was rapid with the organic carbon content of the sediments reaching background level at three months and the benthic community and heavy metal content of the sediments reaching background levels within one year.

Degradation at the site of the new discharge took several years with the initial increase in fish and benthic populations through 1976 followed by a decrease to predischarge levels. However, species composition of the benthos in the vicinity of the discharge changed. Capitella capitata appeared in significant numbers 2-4 years after construction of the new pipeline. The pelecypod Parvilucina tenuisculpta, which is commonly found around offshore domestic sewers in southern California, also appeared in significant numbers at 4-5 years. The copper concentration of the sediment doubled within the initial 5 years and has leveled off since then. The area affected by this discharge now totals $10 \mathrm{~km}^{2}$ (Bascom et al., 1978). 


\section{Hyperion (City of Los Angeles)}

The Hyperion sewage treatment plan discharges 830 million 1/day primary effluent and 380 million 1/day secondary effluent through a diffusor pipe emptying $8 \mathrm{~km}$ from shore in $60 \mathrm{~m}$ depth. Solid wastes totaling $5.3 \mathrm{million}$ 1/day are emptied into the head of the Santa Monica Canyon which is located $11 \mathrm{~km}$ offshore in $100 \mathrm{~m}$ depth. Some benthic samples were taken prior to construction of the new sewer lines. It took 5-7 years for the population of Capitella capitata to build up and the area has been more or less constant in size since that time; $26 \mathrm{~km}^{2}$ of the benthos has either been degraded or stressed in the vicinity of these two discharge points (Bascom et al., 1978).

\section{SYNTHESIS OF BIOLOGICAL DATA}

With the accumulation of a considerable amount of benthic biological data from the environment surrounding many of the domestic outfall sewers in southern California, it is possible to make more or less accurate predictions of what will occur when primary treated domestic wastes are discharged into open oceanic waters. It may be necessary to modify these predictions for areas possessing unique oceanographic conditions or discharges which receive industrial wastes and/or storm water run-off. It would be necessary to take a much more conservative viewpoint if the wastes are emptied into an estuary. Nevertheless, the marine environment can assimilate a certain quantity of domestic wastes without undergoing adverse changes in the environment; in fact, some bioenhancement may occur when the discharge is small (7-10 million 1/day). Degradation was noted to a limited extent at the Oxnard sewer which discharges over 40 million 1/day. The benthic environment can no longer assimilate the waste material when it exceeds 300 million 1/day. The benthic area affected by primary effluent is apparently

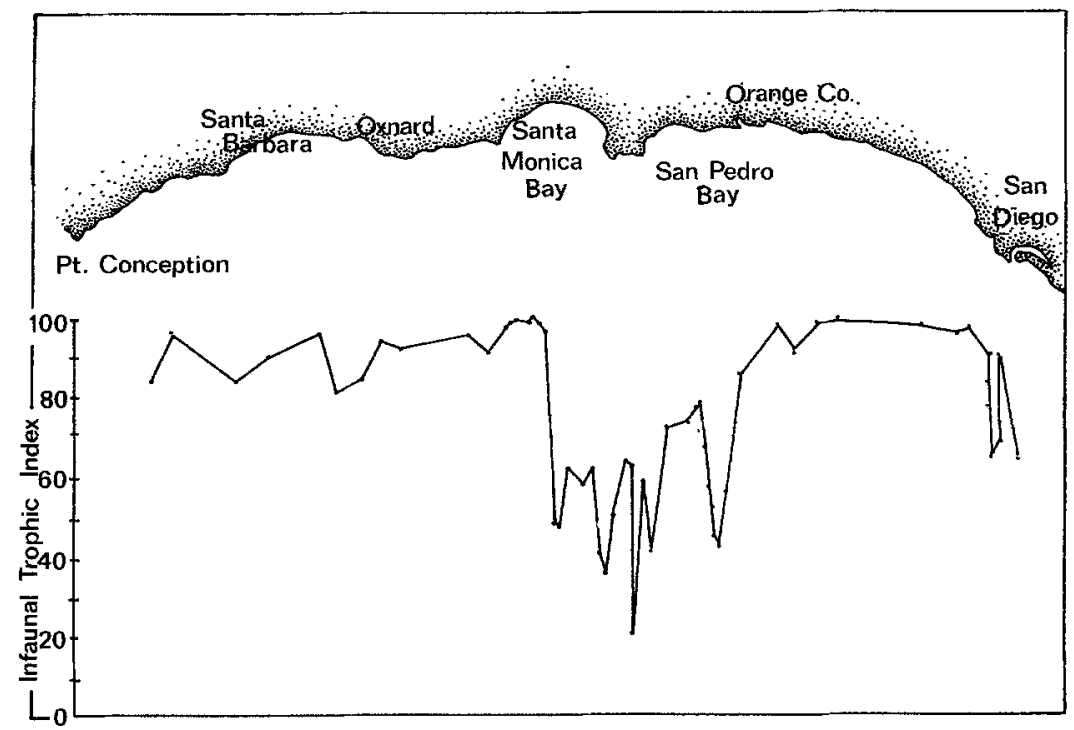

Fig. 1. Infaunal trophic index values for southern California for 1977 (figure modified from Word, J. Q., 1979. Southern California Coastal Water Research Project, Annual Report for 1978, p. 29) 


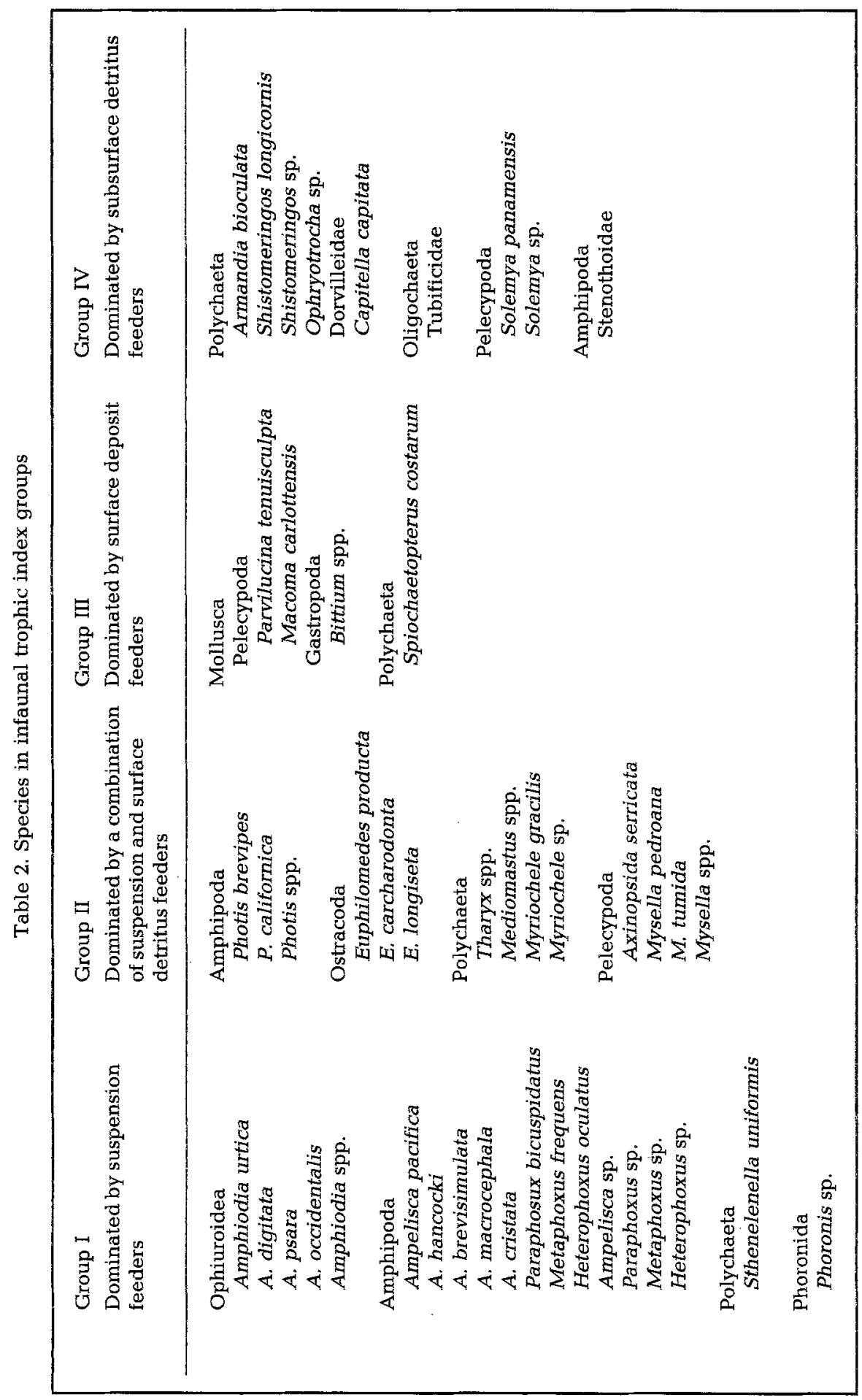


directly related to the volume of the discharge (Table 1). Any proposal to locate a domestic outfall sewer into open oceanic waters must consider the volume of the discharge and its possible effects on the benthic marine biota.

In a more precise synthesis of data the personnel of the Southern California Coastal Water Research Project (Word, 1978) devised an infaunal index which is based on feeding strategies of the dominant benthic species. The selection of the 47 species to be used was made from a list of 770 known to occur in southern California offshore waters. These species were grouped into four categories according to feeding type (Table 2). An index number was calculated for a particular area according to the formula:

$$
\text { Infauna index }=\frac{100-\left[331 / 3\left(0_{n 1}+1_{n 2}+2_{n 3}+3_{n 4}\right)\right]}{n_{1}+n_{2}+n_{3}+n_{4}}
$$

where $n_{1}$ is the number of specimens in group 1, etc. and $331 / 3$ is a scaling factor so that the numbers will range from 1 to 100 . The higher the number the more natural the environment and, conversely, the lower the number the greater the degradation of the area. The graphic representation in Figure 1 clearly indicates the influence of the four largest discharges - Hyperion, Los Angeles County, Orange County, and San Diego. The slight decreases at Santa Barbara and Oxnard may or may not be related to waste discharges.

\section{CONCLUSIONS}

The periodic monitoring of domestic outfall sewers in southern California, in some instances for nearly 25 years, has demonstrated the importance of studying the benthos in assessing the effects of these wastes. If the amount of discharge is large, then the amount of affected area is directly related to the quantity of the discharge. Studies undertaken prior to installation of new sewers discharging large amounts of domestic wastes indicate that the benthic area will become stressed or degraded within 2 to 4 years; however, only about one year is required for the population to become characteristic of a natural area following the elimination of the source of waste. An infaunal index was presented as a means of comparing the population of one affected area with another.

With the continual migration of people to metropolitan centers, many of which are located adjacent to oceanic waters, the elimination of their wastes becomes an even more complex problem. Discharge of large quantities of wastes will affect the area. Do we ignore this degradation? Do we discharge secondary effluent into the ocean and dispose of the solid wastes elsewhere? This was the decision of the U. S. Congress; however, provisions were made in the law to permit the sanitation district to petition for an exception. Action on these petitions will begin in 1980 .

\section{LITERATURE CITED}

Bascom, W., Mearns, A. J. \& Word, J. Q., 1978. Establishing boundaries between normal, changed, and degraded areas. - A. Rep. Southern Calif. coast. Water Res. Proj., El Segundo, Calif. 1977, 81-94.

Schafer, H. A., 1978. Characteristics of municipal wastewater discharges, 1977. - A. Rep. Southern Calif. coast. Water Res. Proj., El Segundo, Calif. 1977, 97-112. 
Turner, C. H., Ebert, E. E., \& Given, R. R., 1965. Survey of the marine environment offshore to San Elijo Lagoon, San Diego County. - Calif. Fish Game 51, 81-112.

Turner, C. H., Ebert, E. E. \& Given, R. R., 1968. The marine environment offshore from Point Loma, San Diego County. - Fish Bull. 140, 1-85.

Word, J. Q., 1978. The infaunal trophic index. - A. Rep. Southern Calif. coast. W. Res. Proj., El Segundo, Calif. 1977, 19-39. 